\title{
IMPLEMENTASI WAKAF UANG DI KSPPS MITRA ANDA SEJAHTERA SEMARANG DAN FUNGSINYA BAGI KESEJAHTERAAN UMAT
}

\author{
Syifa Mufidah ${ }^{1}$, Ida Nurlaeli ${ }^{2}$ \\ 1UIN Walisongo Semarang, syifamufidah50@gmail.com \\ 2UIN Walisongo Semarang, ida nurlaeli@walisongo.ac.id
}

\begin{abstract}
ABSTRAK
Dalam penerapannya wakaf tunai yang mengacu pada model dana abadi dan dapat menerbitkan sertifikat wakaf tunai dengan nominal yang berbeda-beda disesuaikan dengan kemampuan target atau sasaran yang akan dituju. Disinilah letak keunggulan dari wakaf tunai, yaitu dapat menjangkau pada seluruh segmen masyarakat yang beragam. Maka dari itu kami ingin menulis tentang Implementasi Wakaf Uang di KSPPS Mitra Anda Sejahtera Semarang dan Fungsinya Bagi Kesejahteraan Masyarakat, dengan tujuan untuk mengetahui cara penghimpunan, investasi dan penyaluran wakaf uang di KSPPS Mitra Anda Sejahtera. Field research ini dilakukan dengan mengamati dan menilai secara langsung realita yang ada. Dengan pendekatan kualitatif, penelitian ini bersifat deskriptif analitik. Teknik penarikan sampel menggunakan teknik purposive (non random sampling). Penelitian ini menghasilkan bahwa penghimpunan dana wakaf uang di Baitul Maal KSPPS Mitra Anda Sejahtera melalui "jemput bola" ke wakif, syiar di sosial media, pengelolaan wakaf uang dengan investasi deposito, jual beli hewan quban, peminjaman untuk modal usaha dengan bagi hasil, hambatan berupa kurangnya SDM dan relasi yang dimiliki, penyaluran dana wakaf uang untuk program membeli ambulans dan memanfaatkannya untuk pelayanan masyarakat, pengadaan Al-quran di pesantren Tahfidzul Quran, santunan guru, dakwah, kemanusiaan atau bencana alam, kesehatan, anak yatim dan pinjaman kebajikan atau qardhul hasan.
\end{abstract}

Kata-kata kunci : Wakaf Uang, Penghimpunan Dana, Pengelolaan Dana, Penyaluran Dana, Hambatan

\begin{abstract}
In the application of cash waqf that refers to the endowment model and can issue cash waqf certificates with different nominal adjusted to the ability of the target or target to be addressed. Therein lies the advantage of cash waqf, which can reach all diverse segments of society. So from that we want to write about the Implementation of Money Waqf in KSPPS Mitra Sejahtera Semarang and Its Functions for Community Welfare, with the aim to find out how to collect, invest and distribute waqf money at KSPPS Mitra Sejahtera. The research is carried out by directly observing and evaluating the reality. With a qualitative approach, this research is analytic descriptive. The sampling technique uses purposive (non-sampling sampling) techniques. This research results that the raising of endowment funds in Baitul Maal KSPPS Mitra Anda Sejahtera through "picking up the ball" to wakif, sharing on social media, managing waqf money with investment deposits, buying and selling quban animals,
\end{abstract}


lending for venture capital with profit sharing, obstacles in the form of lack of human resources and relationships, distribution of endowment funds for programs to buy ambulances and use them for community services, procurement of the Qur'an at the Tahfidzul Quran boarding school, teacher benefits, propaganda, humanitarian or natural disasters, health, orphans and benevolent loans or qardhul hasan.

Keywords: money waqf, raising funds, managing funds, channeling funds, obstacles

\section{PENDAHULUAN}

Di tengah permasalahan ekonomi dan sosial di Indonesia, wakaf adalah salah satu solusi yang strategis. Selain menjadi ajaran dari agama Islam, nampaknya wakaf ini juga memiliki kekuatan yang berdampak pada ekonomi dan sosial di masyarakat. Namun, masih banyak masyarakat di Indonesia yang masih belum familiar dengan wakaf uang. Karena wakaf pada umumnya masih dikenal dengan pemberian yang bermanfaat bagi masyarakat dengan berbentuk benda mati yang tidak bergerak. Kebutuhan masyarakat pada masa sekarang sangat banyak sehingga mereka membutuhkan dana tunai untuk meningkatkan kesejahteraan.

Wakaf tunai atau uang diperkenalkan oleh seorang pemerhati ekonomi masyarakat M.A. Mannan, seorang berdarah Bangladesh. Lewat inovasi wakaf tunai sebagai salah satu instrument keuangan Islam, ia mengembangkan operasionalisasi pasar modal melalui organisasi Social Investment Bank Ltd (SIBL) yang dibentuknya (Rahman, 2009:88). Yaitu seperti Waqf properties, development bond, cash waqf deposit certificate, dan puluhan lembaga bisnis lainnya. Usaha untuk merevitalisasi unsur wakaf guna memberikan berbagai macam manfaat ekonomi memerlukan terobosan pemikiran tentang konsep tersebut yang sesuai dengan perkembangan yang ada tetapi tidak meninggalkan unsur syari'ah (Mannan, t.th: 94)

Dalam penerapannya, wakaf tunai yang mengacu pada model dana abadi dapat menerbitkan sertifikat wakaf tunai dengan nominal yang berbeda-beda disesuaikan dengan kemampuan target atau sasaran yang akan dituju. Disinilah letak keunggulan dari wakaf tunai, yaitu dapat menjangkau pada seluruh segmen masyarakat yang beragam. Dari segi manfaat utama wakaf tunai memiliki empat hal (Rahman, 2009:88) yakni sebagai berikut: (1) Wakaf tunai jumlahnya bisa variasi sehingga seseorang yang memiliki dana terbatas sudah bisa mulai memberikan dana wakaf, (2) 
Melalui wakaf tunai, aset-aset wakaf berupa tanah-tanah kosong bisa mulai dimanfaatkan dengan pembangunan gedung-gedung dan atau dikelola untuk lahan pertanian serta peternakan, (3) Dana wakaf tunai juga bisa membantu sebagian lembaga pendidikan Islam cash flow-nya terkadang kembang kempis, (4) Umat Islam dapat lebih mandiri dalam mengembangkan dunia pendidikan tanpa harus terlalu bergantung pada anggaran pendidikan Negara yang semakin lama semakin terbatas.Maka dari itu kami ingin menulis tentang Implementasi Wakaf Uang di KSPPS Mitra Anda Sejahtera Semarang dan Fungsinya Bagi Kesejahteraan Masyarakat, dengan permasalahannya antara lain bagaimana penghimpunan, investasi dan penyaluran wakaf uang di KSPPS Mitra Anda Sejahtera.

\section{METODE PENELITIAN}

Jenis penelitian adalah penelitian lapangan (field research), dimana dilakukan dengan mengamati, melihat dan menilai secara langsung realita yang ada. Sedangkan pendekatan penelitian menggunakan pendekatan kualitatif. Penelitian ini bersifat deskriptif analitik, yakni metode dengan cara mencari fakta, dalam hal ini yaitu mengenai wakaf uang, kemudian menarik interpretasi yang tepat kemudian menguraikannya dan menganalisisnya. Teknik penarikan sampel yang dipergunakan adalah teknik purposive (non random sampling). Pengumpulan data dengan cara observasi, wawancara dan dokumentasi. Selanjutnya data yang diperoleh, baik dari studi lapangan maupun studi pustaka dianalisis secara deskriptif kualitatif, yaitu data yang terkumpul dituangkan dalam bentuk uraian logis dan sistematis, selanjutnya dianalisis untuk memeperoleh kejelasan penyelesaian masalah, kemudian ditarik kesimpulan secara deduktif, yaitu dari hal yang bersifat umum menuju ke hal yang bersifat khusus

\section{HASIL DAN PEMBAHASAN}

\section{Pengertian Wakaf Uang}

Di Indonesia sedang menggalakkan bentuk wakaf baru dengan nama Wakaf Tunai (Cash Waqf). Sebenarnya, inti persoalan dalam Wakaf Tunai terletak pada obyek wakafnya, yaitu uang.Karena itu terjemahannya yang lebih tepat adalah Wakaf Uang (Kemenag RI, 2006:44).Wakaf benda bergerak berupa uang yang merupakan terobosan dalam Undang-undang No. 41 Tahun 2004 tentang Wakaf yang dapat dijabarkan sebagai berikut: 1) 
Wakaf uang yang dapat diwakafkan adalah mata uang rupiah, 2) Dalam hal uang yang akan diwakafkan masih dalam mata uang asing, maka harus dikonversi terlebih dahulu ke dalam rupiah, 3) Wakif yang akan mewakafkan uangnya diwajibkan untuk; a) hadir di Lembaga Keuangan Syariah Penerima Wakaf Uang (LKS-PWU) untuk menyatakan kehendak wakaf uangnya, b) menjelaskan kepemilikan dan asal-usul uang yang akan diwakafkan, c) menyetorkan secara tunai sejumlah uang ke LKSPWU, d) mengisi formulir pernyataan kehendak Wakif yang berfungsi sebagai akta ikrar wakaf. Dalam hal Wakif tidak dapat hadir, maka Wakif dapat menunjuk wakil atau kuasanya. Wakif dapat menyatakan ikrar wakaf benda bergerak berupa uang kepada Nazhir di hadapan PPAIW yang selanjutnya Nazhir menyerahkan akta ikrar wakaf tersebut kepada LKS (Kemenag RI, 2006:69-70). Dinamika praktik wakaf di Indonesia awalnya banyak dipraktikkan oleh organisasi sosial keagamaan, sehingga menyebabkan objek wakaf termanifestasi dalam wujud masjid, sekolah, pesantren, dan berbagai praktik sosial keagamaan lainnya (Makhrus, 2018: 221).

Wakaf tunai (cash waqf) sudah dipraktikan sejak awal abad kedua hijriyah. Imam Azzuhri (wafat $124 \mathrm{H}$ ) memfatwakan, dianjurkan untuk mewakafkan dinar dan dirham untuk pembangunan sarana dakwah, sosial, dan pendidikan umat Islam. Adapun caranya adalah menjadikan uang tersebut sebagai modal usaha kemudian menyalurkan keuntungannya sebagai wakaf, sebagai konsep sosial yang memiliki dimensi ibadah, wakaf juga disebut amal shodaqah jariyah, dimana pahala yang didapat oleh wakif akan selalu mengalir selama harta tersebut masih ada dan bermanfaat. Dengan demikian harta wakaf tersebut menjadi amanat Allah kepada orang atau badan hukum (sebagai nazir) yang mengurus dan mengelolanya (Dirjen Bimas Islam Kemenag RI, 2006:69). Namun, wakaf tidak hanya segala sesuatu yang memberikan manfaat dalam hal kontribusi amalan beribadah kepada Allah tetapi juga segala sesuatu yang memberikan manfaat bagi orang lain atau bernilai sosial.

Teori Kesejahteraan Menurut Suharto Edy menyatakan bahwa: "Kesejahteraan sosial adalah sebagai arena atau domain utama tempat berkiprah pekerjaan sosial artinya kesejahteraan sosial sebagai arena penempatan sarana atau wahana atau alat (means) untuk mencapai tujuan pembangunan". Dari pendapat diatas dapat ditarik kesimpulan tentang 
kesejahteraan masyarakat yaitu suatu keadaan atau kondisi yang terjamin keadaannya dan tercukupi segala kebutuhan baik fisik (makan, minum) dan maupun secara material (kepemilikan sandang dan papan). Kesejahteraan masyarakat juga dapat diukur dari kemandirian masyarakat tersebut didalam memenuhui segala kebutuhannya baik material mauapun spiritual (Suharto, 2005:3).

Wakaf tunai dalam definisi Departemen Agama adalah wakaf yang dilakukan oleh seseorang, atau sekelompok orang, dan lembaga atau badan hukum yang berbentuk uang. Dengan demikian, wakaf uang merupakan wakaf yang diserahkan oleh waqif kepada nadzir dalam bentuk uang kontan (Djunaidi, 2007:3). Hal ini selaras dengan fatwa yang dikeluarkan oleh Komisi Fatwa Majelis Ulama Indonesia (MUI, 2003:85) mengenai wakaf pada tanggal 11 Mei 2002, yang menyatakan bahwa :

a. Wakaf Uang (Cash Wakaf/Waqf al-Nuqud) adalah wakaf yang dilakukan seseorang, kelompok orang, lembaga atau badan hukum dalam bentuk tunai;

b. Termasuk ke dalam pengertian uang adalah surat berharga;

c. Wakaf Uang hukumnya jawaz (boleh);

d. wakaf uang hanya boleh disalurkan dan digunakan untuk hal-hal yang diperbolehkan secara syar'i;

e. Nilai pokok Wakaf Uang harus dijamin kelestariannya, tidak boleh dijual, dihibahkan dan/atau diwariskan.

Dengan demikian, wakaf uang hukumnya boleh baik menurut undang-undang maupun agama,

Menahan harta yang dapat dimanfaatkan tanpa lenyapnya bendanya atau pokoknya, dengan cara melakukan tindakan hukum terhadap benda tersebut (menjual, memberikan, atau mewariskannya), untuk disalurkan (hasilnya) pada sesuatu yang mubah (tidak haram) yang ada.

Dalam definisi di atas, wakaf tidak lagi terbatas pada benda yang tetap wujudnya, melainkan wakaf dapat berupa benda yang tetap nilainya atau pokoknya. Uang masuk dalam kategori benda yang tetap pokoknya. Dengan demikian, definisi MUI di atas memberikan legitimasi kebolehan wakaf tunai. Dasar hukum wakaf uang tentunya juga berlandaskan Al-quran, Hadits, dan Ijma' Ulama. Dasar hukum wakaf uang bersumber 
QS. Ali-Imron ayat 92

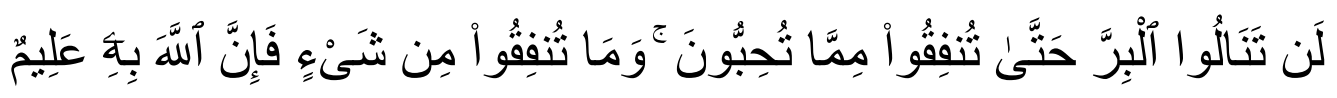

"Kamu sekali-kali tidak sampai kepada kebaikan (yang sempurna) sebelum kamu menafkahkan sebagian harta yang kau cintai. Dan apa saja yang kamu nafkahkan, maka sesungguhnya Allah Maha Mengetahui."

Sebagai upaya yang konkrit agar wakaf tunai dapat diserap dan dipraktikan di tengah-tengah masyarakat, yang perlu diperhatikan adalah (Dirjen Bimas Islam Kemenag RI, 2006:7): Pertama, metode penghimpunan dana (fundrising), yaitu bagaimana wakaf uang itu dimobilisasikan. Dalam hal ini, sertifikat merupakan salah satu cara yang paling mudah, yaitu dengan menerbitkan sertifikat dengan nilai yang berbeda-beda untuk kelompok sasaran yang berbeda. Aspek inilah yang merupakan keunggulan wakaf uang dibandingkan wakaf harta tetap lainnya. Karena besarnya dapat menyesuaikan kemampuan calon waqif. Kedua, pengelolaan dana yang berhasil dihimpun. Orientasi dalam mengelola dana tersebut adalah bagaimana pengelolaan tersebut mampu memberikan hasil yang semaksimal mungkin (income genmerating orientation). Implikasinya adalah bahwa dana-dana tersebut mesti diinvestasikan pada usaha-usaha produktif. Ketiga, distribusi hasil yang dapat diciptakan kepada para penerima manfaat (beneficiaries). Dalam mendistribusikan hasil ini yang perlu diperhatikan adalah tujuan atau orientasi dari distribusi tersebut, yang dapat berupa penyantunan (charity), pemberdayaan (empowerment), investasi sumber daya insane (human investment), maupun investasi infrastruktur (infrastruktur investmen).

2. Penghimpunan Wakaf Uang

Perhimpunan dana (fundraising) merupakan kegiatanpenggalangan dana, baik dari individu, organisasi, maupun badanhokum (Rozalinda, 2015:138). Dalam melakukan kegiatan fundraising, banyak metode dan teknik yang dapat dilakukan. Pada dasarnya ada dua jenis yang bisa digunakan yaitu langsung (direct fundraisaing) dan tidak langsung (indirect). Metode langsung adalah metode yang menggunakan teknik-teknik atau cara-cara yang melibatkan partisipasi wakif secara langsung. Yakni bentuk-bentuk fundraising dimana proses interaksi dan daya akomodasi terhadap respons wakif bisa seketika dilakukan. Misalnya, melalui direct mail, direct advertising, telefundraising, dan presentasi langsung. Metode 
fundraising tidak langsung dan merupakan suatu metode yang menggunakan teknik atau cara yang tidak melibatkan partisipasi wakif secara langsung. Metode ini dilakukan dengan metode promosi yang mengarah kepada pembentukan citra lembaga yang kuat, tanpa diarahkan untuk transaksi donasi pada saat itu. Misalnya advertorial, image campaign, dan penyelenggaraan suatu kegiatan melalui perantara, menjalin relasi, melalui referansi, dan mediasi para tokoh (Rozalinda, 2015:139).

Di Indonesia praktik wakaf uang baru mendapat dukungan Majelis Ulama Indonesia pada tahun 2002 seiring dengan dikeluarkan keputusan Fatwa Komisi Fatwa Majelis Ulama Indonesia tentang Wakaf Uang tanggal 28 Shafar 1423 Hijriah atau 11 Mei 2002 guna menjawab Surat Direktur Pengembangan Zakat dan wakaf Departemen Agama Nomor Dt.1.III/5BA.03.2/ 2772/2002 tanggal 26 April 2002 yang berisi tentang permohonan wakaf uang (Usman, 2013:106).Kebolehan wakaf uang ini kemudian dikukuhkan atau dipertegas kembali melalui undang-undang No. 41 tahun 2004 tentang wakaf. Berdasarkan undang-undang No. 41 tahun 2004, benda yang dapat diwakafkan tidak hanya benda tetap, melainkan juga benda-benda bergerak, yaitu harta benda yang tidak bisa habis karena dikonsumsi meliputi uang, logam mulia, surat berharga, kendaraan, hak atas kekayaan intelektual, hak sewa, dan benda bergerak lain sesuai dengan ketentuan syariah dan peraturan perundang-undangan yang berlaku, antara lain seperti mushaf, buku, dan kitab (Usman, 2013:110).

Adapun benda bergerak berupa uang dijelaskan dalam pasal 22 dan 23 (PP, 2006). Dalam pasal 22 dijelaskan bahwa: 1) Wakaf tunai yang dapat diwakafkan adalah mata uang rupiah, 2) Dalam hal uang yang akan diwakafkan masih dalam mata uang asing, maka harus dikonversi terlebih dahulu ke dalam rupiah, 3) Wakif yang akan mewakafkan uangnya diwajibkan untuk; a) hadir di lembaga keuangan syari'ah penerima wakaf tunai (LKS-PWU) untuk menyatakan kehendak wakaf tunainya, b) menjelaskan kepemilikan dan asal-usul uang yang akan diwakafkan, c) menyetor secara tunai sejumlah uang ke LKS-PWU, d) mengisi formulir pernyataan kehendak wakif yang berfungsi sebagai AIW.Pasal 23 menjelaskan bahwa Wakif dapat mewakafkan benda bergerak berupa uang melalui LKS yang ditunjuk oleh Menteri sebagai LKS penerima wakaf uang (LKS-PWU). Hingga saat ini, sudah ada 5 LKS-PWU yang diresmikan oleh 
Menteri Agama, yakni Bank Muamalat, Bank Mega Syariah, Bank Syariah Mandiri, Bank BNI Syariah, dan Bank DKI (Sudirman, 2009:6).

Sertifikat Wakaf Uang (SWU) merupakan inovasi instrument finansial, keuangan sosial dan perbankan sosial. Yang pertama kali dalam sejarah. Wakaf uang sebagai instrument keuangan sungguh merupakan suatu produk baru dalam sejarah perbankan Islam.Pemanfaatan wakaf uang dapat dibedakan menjadi dua, yaitu pengadaan barang privat dan barang sosial. Operasionalisasi sertifikat wakaf uang dapat dijabarkan ke dalam beberapa hal, sebagai berikut (Hasan, 2011:55): 1) Wakaf uang harus diterima sebagai sumbangan yang sesuai dengan tuntutan syariah. Sedangkan bank yang bertindak sebagai Nazhir harus mengelola wakaf tersebut atas nama wakif, 2) Wakif memiliki kebebasan memilih untuk tujuan apa dana hibah yang ia berikan, 3) Wakaf uang dilakukan dengan tanpa batas waktu dan rekeningnya harus terbuka dengan nama yang telah ditentukan oleh wakif, 4) Wakaf uang selalu menerima pendapatan dengan tingkat (rate) tertinggi yang ditawarkan bank dari waktu ke waktu, 5) Kualitas wakaf tetap utuh dan hanya keuntungannya saja yang dibelanjakan untuk tujuan-tujuan yang telah ditentukan oleh wakif. Bagian keuntungan yang tidak dibelanjakan secara otomatis ditambahkan pada wakaf dan profit yang diperoleh akan bertambah terus, 6) Wakif dapat meminta bank untuk mmpergunakan keseluruhan profit untuk tujuan-tujuan yang telah ditentukan, 7) Wakif dapat memberikan wakaf uang untuk sekali saja, atau ia dapat juga menyatakan akan memberikan sejumlah wakaf dengan cara melakukan deposit pertama kalinya sebesar yang ditentukan. Deposit-deposit berikutnya juga dapat dilakukan dengan pecahan masing-masing atau kelipatannya, 8) Wakif juga dapat meminta kepada bank untuk merealisasikan wakaf uang pada jumlah tertentu untuk dipindahkan dari rekening wakif kepada pengelola harta wakaf (Nazir), 9) Setiap setoran uang harus diberikan tanda terima dan setelah jumlah wakaf uang tersebut mencapai yang ditentukan barulah diterbitkan sertifikat wakaf uang (SWU), 10) Prinsip dan dasar peraturan syari'ah tentang wakaf uang dapat ditinjau kembali dan dapat berubah.

\section{Pengelolaan Wakaf Uang}

Cara melakukan wakaf uang menurut Mazhab Hanafi ialah menjadikannya modal usaha dengan mudharabah atau mubadha'ah. Sedangkan keuntungannya disedekahkan kepada pihak wakaf. Pendapat 
ini didukung oleh Ibn Jibrin (//ibn-jebreen.com), salah satu ulama modern, bahwa wakaf uang harus diberdayakan sehingga mampu memberikan kemudahan dalam membantu orang-orang yang secara ekonomi kurang beruntung (Hasan, 2011:168).

Pada wakaf uang, dana wakaf yang diperoleh dari para wakif akan dikelola oleh nazhir (pengelola wakaf) yang dalam hal ini bertindak sebagai manajemen investasi. Para waqif tersebut mensyaratkan kemana alokasi pendistribusian keuntungan investasi wakaf nantinya. Kemudian dana wakaf tersebut dikelola dan diinvestasikan sebagian pada instrument keuangan syariah, sebagian lagi diinvestasikan langsung ke berbagai badan usaha yang bergerak sesuai syariah, dapat juga diinvestasikan untuk mendanai pendirian badan usaha baru. Keuntungan dari investasi tersebut dapat disaluran kepada masyarakat miskin melalui pengadaan dana kesehatan, pendidikan, rehabilitasi keluarga, bencana alam, dan lain sebagainya yang persentasenya sesuai dengan permintaan atau kesepakatan waqif dan tidak melanggar syariat. Adapun uang pokoknya akandiinvestasian terus menerus sehingga ummat memiliki dana yang selalu ada dan insya Allah akan terus bertambah seiring dengan bertambahnya jumlah waqif (Usman, 2013:117)

Investasi wakaf sebetulnya memiliki keunikan tersendiri yang membedakannya dengan investasilain.Pertama, investasi wakaf walaupun ditujukan pada sektor produktif yang dapat mendatangkan keuntungan secara pasti. Kedua, aset yang diwakafkan harus terus terpelihara dan berkembang (Kahf, 1998:8-9). Tujuan utama investasi wakaf adalah untuk menjaga harta benda wakaf dan mendapatkan keuntungan sebesar mungkin. Terdapat beberapa standar yang harus diperhatikan dalam investasi harta benda wakaf yang menjadi landasan pengawasan syariah, yaitu (Zamhari, 2013:169): 1) Bidang investasi harus halal dan terhindar dari yang diharamkan, 2) Menggunakan pola investasi Islam dan dalam implementasinya syarat dan rukunnya sesuai dengan kaidah fikih, 3) Melakukan visibility study sebelum memulai investasi demi menjamin terealisasinya tujuan investasi, 4) Mengikuti syarat-syarat waqif apabila ia menentukan pola-pola investasi tertentu, 5) Memilih pola investasi yang bisa menghasilkan keuntungan paling besar. Investasi tidak boleh mengakibatkan hilangnya kepemilikan wakaf, seperti pola persewaan yang berakhir dengan kepemilikan, 6) Memperbanyak sebaran investasi untuk 
mengurangi resiko, 7) Investasi dilakukan di negara tempat harta benda wakaf berada agar keuntungannya dinikmati oleh warga negara itu, 8) Mewaspadai risiko dengan menerapkan manajemen risiko, 9) Pengawasan secara kontinyu terhadap investasi untuk mengetahui progress dan kesesuaian pekerjaan dengan ketentuan, dan menanyakan setiap bentuk pelanggaran yang terjadi untuk diluruskan secepatnya.

Wakaf produktif berdasarkan pengelolaan danpengembangan hartayang diwakafkan. Dalam hal ini juga dikelompokkan menjadi dua bentuk yakni (Ishom, 2014:674): mubasyir/dzati; harta wakaf yang menghasilkan pelayanan masyarakat dan bisa digunakan secara langsung seperti madrasah dan rumah sakit. Mistitsmary, yaitu harta wakaf yang ditujukan untuk penanaman modal dalam produksi barang-barang dan pelayanan yang dibolehkan syara' dalam bentuk apapun kemudian hasilnya diwakafkan sesuai keinginan pewakaf. Dalam peraturan pemerintah no 46 tahun 2006 pasal 48 dijelaskan bahwa pengelolaan dan pengembangan atas harta benda wakaf uang hanya dapat dilakukan melalui investasi pada produk-produk LKS dan/ atau instrument keuangan syariah. Menurut pasal ini instrumen investasi wakaf uang terdiri dari dua sektor; Investasi pada lembaga keuangan syariah dan instrument syariah lainnya. Selain itu, investasi wakaf uang sebenarnya dapat dilakukan pada sector riil seperti pembiayaan usaha kecil menengah (UKM) dan usaha mikro (Maksum: 9). Investasi melalui bank syariah dijaminkan melalui lembaga penjamin simpanan, investasi diluar bank dijaminkan melalui asuransi syariah. Ruang lingkup investasi syariah diantaranya adalah deposito mudharabah, reksadana syariah (Islamic investment fund) saham syariah di pasar modal syariah, obligasi syariah dan sukuk (Islamic bonds), (Rozalinda, 2015:141).

\section{Penyaluran Hasil Wakaf Uang}

Pembelian sertifikat wakaf uang dapat dilakukan dengan maksud untuk memenuhi target investasi sedikitnya empat bidang yaitu (Hasan, 2011:57-58): Kemanfaatan bagi kesejahteraan pribadi, Kemanfaatan bagi kesejahteraan keluarga, Pembangunan social, Bantuan untuk kesejahteraan masyarakat (Hasan, 2011:57-58).

Para ulama juga sepakat, bahwa wakif berhak menentukan mauqufalaih yang berhak mendapatkan hasil pengelolaan wakaf uang. Hak 
ini dibatasi dengan ketentuan-ketentuan sebagaimana sebagaimana di atas, yaitu tidak bertentangan dengan hukum-hukum Islam dan maksud dari wakaf uang, yakni (Abu Zahrah, 1971:187-188): 1) Wakaf uang digunakan untuk kebaikan. Contohnya yaitu menyalurkan hasilnya untuk kebaikan yang berguna bagi manusia di dunia dan akhirat, 2) Wakaf uang tidak untuk maksiat. Jika wakif menentukan agar hasil disalurkan untuk maksiat, maka ketentuannya tidak sah, 3) Hasil wakaf uang tidak untuk diri sendiri. Seperti wakif menentukan seluruh hasil wakaf uang atau sebagiannya untuk dirinya sendiri. Ulama Malikiyah menyatakan hal itu tidak boleh namun ketentuan dari wakif ini tidak membatalkan wakaf uang, 4) Wakaf uang untuk orang kaya. Pandangan mazhab Hanafi membolehkan jika disyarakatkan untuk orang miskin setelah yang kaya. Sementara, mazhab Maliki membolehkannya secara mutlak. Karena wakaf termasuk kategori hibah bukan sedekah. Karena itu sah berwakaf untuk orang kaya dan miskin. Itu pula yang menjadi pendapat paling shahih dari mazhab Syafi'i dan mazhab Hambali.

Koperasi Simpan Pinjam dan Pembiayaan Syariah (KSPPS) Mitra Anda Sejahtera merupakan koperasi simpan pinjam yang aktivitasnya meliputi simpanan, peminjaman, dan pembiayaan mikro untuk semua anggotanya. KSPPS Mitra Anda Sejahtera mengalami perubahan nama karena aturan dari pemerintah yang mengharuskan untuk berubah. Sama dengan KSPPS atau BMT pada umumnya. Awal berdirinya KSPPS Mitra Anda Sejahtera ini bernama BMT yaitu Baitul MaalwaTamwil. Namun pada tahun 2016 Menteri Koperasi membuat kebijakan mengubah nama BMT menjadi KSPPS sehingga berada dibawah naungan menteri koperasi.

Baitul maal di KSPPS Mitra Anda Sejahtera lebih dikenal dengan Baitul Maal Anda.Pada mulanya pengelola hanya menghimpun zakat, infaq dan shodaqoh saja. Namun seiring berjalannya waktu pengelola melihat banyak peluang pada produk wakaf. Selain itu wakaf juga memiliki kemanfaatan jangka panjang karena lebih produktif dibanding zakat, infaq dan shodaqoh. Wakaf lebih sering dikenal oleh masyarakat dengan tanah, masjid, sumur atau bangunan mati lainnya. Namun baitul Maal Anda mengkaji lebih dalam lagi sehingga membuat produk baru yaitu wakaf uang. Baitul Maal di KSPPS Mitra Anda menghimpun wakaf uang sejak tahun 2015. 
a. Penghimpunan

Penghimpunan dana (fundraising) merupakan kegiatan penggalangan dana, baik dari individu, organisasi, maupun badan hokum (Republika;2008). Fundrising mempunyai peranan yang sangat penting bagi perkembangan organisasi pengelola wakaf dalam rangka pengumpulan dana wakaf dari masyarakat. Sebelum turun lapangan, pengelola Baitul Maal Anda melakukan perencanaan secara terjadwal terlebih dahulu. Membuat daftar target sasaran yang prospek untuk diajak bekerjasama menghimpun wakaf tunai. Membuat daftar perencanaan ini bisa dalam berupa mengunjungi perorangan, lembaga, atau membuat program acara maupun sistem yang masif yang dapat menghimpun sebanyak-banyaknya wakaf. Penghimpunan Wakaf tunai Baitul Maal dilakukan melalui beberapa cara diantaranya adalah dengan menyebar kotak wakaf tunai di warung-warung makan atau kerjasama dengan lembaga-lembaga tertentu. Selain itu tentu dengan cross selling pada setiap teller yang ada di kantor pusat atau kantor kas kepada setiap anggota yang melakukan transaksi. Pada pembiaayaan divisi Tamwil, juga dilakukan penawaran kepada anggota untuk berwakaf uang ketika melakukan pencairan pembiayaan. Pada produk arisan berhadiah tahap 3, KSPPS Mitra Anda juga menawarkan wakaf uang pada saat pencairannya. Penghimpunan pada simpanan berhadiah tahap 3 sendiri terkumpul wakaf uang hingga melebihi 5 juta.

Selain menawarkan melalui cross selling, menghimpun wakaf uang juga dilakukan dengan cara jemput bola. Yaitu dengan melakukan perencanaan siapa saja yang akan ditawarkan mengenai wakaf uang atau mensosialisasikan dengan lembaga-lembaga yang dapat ditawarkan untuk bekerjasama. Sosialisasi ini bertujuan melakukan edukasi kepada masyarakat tentang manfaat dan tujuan dari wakaf uang yang banyak masyarakat belum memahami secara baik. Target yang ditawarkan yaitu diantaranya adalah pengusaha, ustadz yang memiliki jamaah atau pondok, maupun orang-orang yang memiliki potensi memberikan wakaf dan dapat menambah relasi untuk berwakaf uang. Dalam melakukan penawaran hal yang pertama dilakukan adalah pendekatan dengan cara bersilaturrahmi kepada calon waqif. Dengan pola pendekatan penyadaran akan 
problem-problem sosial yang sekarang terjadi diharapakan para calon wakif semakin tergerak hatinya menyumbangkan sebagian harta menjadi wakaf (shadaqah jariyyah) untuk kepentingan masyarakat umum.

Di zaman yang serba digital ini tentu penghimpunan melalui sosial media tidak terlupakan. Penghimpunan dengan cara melakukan pencitraan di sosial media, melakukan edukasi dan menyebar manfaat dari hasil wakaf uang secara terus menerus guna mencari perhatian dan menarik netizen atau masyarakat. Dari mulai menyebar apa itu pengertian wakaf uang, manfaat wakaf uang, sasaran dan tujuan wakaf uang diberikan kepada siapa atau untuk apa saja. Kemudian uang yang ingin diwakafkan dapat ditransfer ke rekening baitul maal, datang langsung ke KSPPS Mitra Anda Sejahtera atau bisa juga dengan layanan jemput wakaf. Bekerjasama dengan komunitas-komunitas yang ada di Semarang dengan memberikan sponsor juga sebagai cara untuk menggalang dana pada setiap event yang dilakukan oleh komunitas. Dalam upaya penghimpunan juga perlu dilakukannya sebuah pencitraan semenarik mungkin. Dokumentasi dari penghimpunan dan penyaluran sangat berarti untuk sosialisasi terhadap masyarakat agar dapat menghimpun dana wakaf uang lebih banyak lagi.

Kelemahan dan tantangan dari penghimpunan wakaf uang tentu ada sehingga pelaksanaan menghimpun menjadi kurang optimal. Diantaranya adalah kekurangan SDM yang komitmen dan kompeten terhadap wakaf uang. Karena dalam divisi baitul Maal di KSPPS Mitra Anda Sejahtera hanya dua karyawan yang benar-benar fokus terhadap Baitul Maal.Sedangkan program atau produk yang ingin dicapai tidak hanya wakaf uang saja tetapi juga ada infaq, sedekah, zakat dan juga yang lainnya. Sedikit SDM yang fokus terhadap Baitul Maal juga mempengaruhi relasi yang dimiliki untuk menghimpun lebih banyak dana. Hal lain yang menjadi kendala Baitul Maal di KSPPS Mitra Anda Sejahtera dalam mengembangkan dan mengelola wakaf uang adalah paradigma masyarakat tentang wakaf. Selama ini sebagian umat Islam telah familiar dengan mewakafkan harta bendanya dengan sesuatu yang tetap (tidak bergerak) seperti tanah, namun untuk mewakafkan berupa uang belum familiar. Masyarakat masih berfikiran 
bahwa berwakaf yang lebih afdhol adalah dengan harta benda secara langsung seperti tanah, masjid, sumur dan contoh benda tidak bergerak yang lainnya. Paradigma ini diakui menjadi tantangan bagi pengelola wakaf uang seperti Baitul Maal KSPPS Mitra Anda Sejahtera.

Dalam berwakaf uang di Baitul Maal KSPPS Mitra Anda Sejahtera, tidak hanya memberikan uang atau berpindahnya kepemilikan uang antara pemberi wakaf menjadi milik Baitul Maal. Tetapi juga dapat dengan cara meminjamkan uang kepada Baitul Maal dalam kurun waktu tertentu yang kemudian dapat dimanfaatkan uang tersebut sehingga menghasilkan keuntungan atau bagi hasil lagi kemudian uang pokok tersebut diambil oleh pemilik semula dan bagi hasil yang didapat diberikan untuk Baitul Maal. Jika di KSPPS Mitra Anda Sejahtera, hal ini di sebut Sijangkung (simpanan berjangka). Untuk penghimpunan dana wakaf tunai adalah dengan Aksi Cepat Tanggap (ACT). Aksi Cepat Tanggap memiliki program yang fokus pada penghimpunan, pengelolaan dan penyaluran wakaf yang bernama Global Wakaf.Penghimpunan dari Global Wakaf ini lebih memanfaatkan sosial media seperti instagram yang terus menyebarkan syiar tentang wakaf dengan memberikan info rekening penghimpunan.Akun instagam yang dimiliki oleh ACT adalah @actforhumanity dan akun instagram ACT yang fokus kepada program wakaf adalah @globalwakaf.Selain menggunakan instagram, ACT juga menggunakan link www.kitabisa.com yang dapat dengan mudah diakses oleh masyarakat.

Baitul Maal Anda menggunakan cara global wakaf untuk syiar atau melakukan promosi penghimpunan wakaf uang. Penghimpunan yang dilakukan oleh BMT Anda adalah dengan cara melakukan promosi atau syiar di sosial media seperti facebook, instagram, whattsapp dan web. Instagram yang dimiliki Baitul Maal Anda adalah @BaitulMaalAnda dan akun facebook yang dimiliki adalah Baitul Maal Anda.Website Resmi Baitul Maal Mitra Anda Sejahtera dapat diakses di www.mitraanda.id.Sedangkan whattsapp hanya memanfaatkan dengan menyebarkan syiar atau ajakan seluas-luasnya. Penyetoran wakaf uang Baitul Maal Anda juga bisa dengan mengakses www.wakafuang.id Dengan cara-cara tersebut, sejak tahun 2015 hingga 2018 akhir, perolehan wakaf uang Baitul Maal Anda sebagai berikut: 
Tabel 1 : Penghimpunan Wakaf Uang Desember 2016 - Juni 2018

\begin{tabular}{lll}
\hline \multicolumn{1}{c}{ Bulan/Tahun } & Jumlah wakaf uang & Jumlah wakif \\
\hline Desember 2016 & Rp. 6,822,300 & \\
Desember 2017 & Rp. 13,136,100 & \\
Januari 2018 & Rp. 648,278 & 86 orang \\
Februari 2018 & Rp. 910,200 & 121 orang \\
Maret 2018 & Rp. 908,300 & 121 orang \\
April 2018 & Rp. 558,015 & 74 orang \\
Mei 2018 & Rp. 676,500 & 90 orang \\
Juni 2018 & Rp. 1,312,300 & 174 orang \\
Juli 2018 & Rp. 338,900 & 45 orang \\
Agustus 2018 & Rp. 626,479 & 83 orang \\
September 2018 & Rp. 997,500 & 132 orang \\
Oktober 2018 & Rp. 1,077,496 & 143 orang \\
Nopember 2018 & Rp. 1,552,095 & 206 orang \\
Desember 2018 & Rp. 477,500 & 63 orang \\
Total & Rp. 30,041,963 & 1339 orang \\
\hline
\end{tabular}

Tabel 2: Data Penghimpunan Wakaf di Baitul Maal KSPPS Mitra Anda Sejahtera tahun 2018

\begin{tabular}{ll}
\hline Bulan & Nominal Wakaf (Rp) \\
\hline Januari & 779.031 \\
Februari & 1.178 .057 \\
Maret & 743.500 \\
April & 398.726 \\
Mei & 408.310 \\
Juni & 639.473 \\
Juli & 624.456 \\
Agustus & 1.395 .579 \\
September & 2.453 .652 \\
Oktober & 3.062 .802 \\
November & 6.282 .293 \\
Jumlah & 11.683 .586 \\
\hline
\end{tabular}

BMT Anda juga menyiasati dengan membuat voucher sejenis kupon atau tiket kecil kepada wakif dengan nominal tertentu apabila ingin menyalurkan wakaf uang. Selain itu, BMT Anda menggunakan kotak kecil sepeti kotak infaq yang berisi ajakan untuk berwakaf uang. Dalam pengisian kotak wakaf uang tersebut, tidak jelas nama penyetor (wakif) dan berapa nominal yang diberikan. Seperti dalam Peraturan Pemerintah Republik Indonesia No. 42 tahun 2006 tentang Pelaksanaan Undang-Undang No. 41 tahun 2004 tentang Wakaf pasal 1 sebagai berikut, "Sertifikat Wakaf Uang adalah surat bukti yang dikeluarkan 
oleh Lembaga Keuangan Syariah kepada Wakif dan Nazhir tentang penyerahan wakaf uang." Selain iu, dalam aturan yang telah dibuat tidak memandang kecanggihan teknologi dan perkembngan zaman yang menjadikan semua serba praktis, cepat dan mudah seperti dalam Peraturan Pemerintah Nomor 42 tahun 2006 tentang pelaksanaan Undang-Undang Nomor 41 tahun 2004 tentang Wakaf pasal 22 sebagai berikut: Wakif yang akan mewakafkan uangnya diwajibkan untuk: (a) Hadir di lembaga keuangan syari'ah penerima wakaf tunai (LKS-PWU) untuk menyatakan kehendak wakaf tunainya, (b) Menjelaskan kepemilikan dan asal-usul uang yang akan diwakafkan, (c) Menyetor secara tunai sejumlah uang ke LKS-PWU, d) Mengisi formulir pernyataan kehendak wakif yang berfungsi sebagai AIW.

Penghimpunan yang menggunakan aplikasi atau dengan cara transfer memiliki kelemahan yaitu tidak dapat menghadirkan wakif secara langsung sehingga wakif tidak dapat menjelaskan secara mendetail tentang asal-usul sumber dana wakaf uang yang disetokan, tidak dapat mengisi form dan tidak dapat mengucapkan ikrar. Berbagai cara/ pilihan dalam penghimpunan wakaf uang disesuaikan oleh lembaga berdasarkan dengan kemampuan dari lembaga itu sendiri yang dapat memudahkan nasabah atau wakif. Solusi untuk menghadapi kendala tersebut maka harus dilakukan jemput bola, atau melakukan inovasi dalam penghimpunan seperti membuat aplikasi yang bebasis data atau isi formulir secara online atau persetujuan ikrar yang dapat dilakukan dimana saja.Dalam menangani kendala kurangnya pengetahuan masyarakat tentang wakaf uang, maka yang pelu dilakukan oleh lembaga adalah memberikan edukasi kepada nasabah dengan artikel, kajian, atau promosi melalui media sosial tentang keutamaan dan keistimewaan wakaf uang dengan sangat baik.

b. Pengelolaan

Dalam mengelola wakaf uang di Baitul Maal Mitra Anda Sejahtera, salah satu upaya yang dilakukan adalah jual beli hewan qurban. Dengan bekerjasama dengan anggota KSPPS Mitra Anda Sejahtera yang memiliki usaha hewan qurban, maka Baitul maal Mitra Anda Sejahtera menjualkan atau menjadi agen reseller yang mendapatkan keuntungan yang telah disepakati. Penjualan hewan qurban ini memiliki resiko kerugian yang sangat kecil karena telah ada 
penjaminan dari pemilik hewan qurban apabila hewan qurban telah meninggal sebelum hari penyembelihan, maka uang akan kembali. Keuntungan yang di dapat pada sekali musim qurban cukup menjanjikan. Kendala yang terjadi yaitu modal yang dimiliki dari sumber penghimpunan wakaf uang tidak terlalu banyak. Sehingga tidak bisa membiayai dengan jumlah besar. Selain itu promosi atau sosialisasi kepada masyarakat kurang luas. Selain kendala modal atau jumlah penghimpunan wakaf uang yang sedikit, karyawan KSPPS Mitra Anda Sejahtera kurang masif dalam memasarkan, lokasi hewan qurban yang cukup jauh dari kantor juga membuat anggota atau calon pembeli yang ingin melihat hewan qurban mengurungkan niat untuk berqurban.

Kendala yang ditemui oleh Baitul Maal KSPPS Mitra Anda sejahtera dalam mengelola wakaf uang yaitu bagaimana menginvestasikan dengan resiko yang sedikit namun memberikan keuntungan yang banyak. Pendapatan keuntungan Baitul Maal dalam hal wakaf masih sedikit jika dibandingkan dengan Baitut tamwil. Karena baitul tamwil lebih dikenal oleh masyarakat tentang program-program yang dimilikinya. Kendala lain adalah pengelola kurang bisa membaca prospek usaha yang tepat di masyarakat agar usaha yang dilakukan tidak mengalami kerugian. Solusinya adalah melakukan kerjasama dengan berbagai jenis usaha masyarakat khususnya menengah kebawah yang usahanya sudah stabil dan membutuhkan modal. Baitul Maal bisa menanamkan modal dan mendapatkan keuntungan tanpa harus melakukan dan megelola usaha secara langsung.

c. Penyaluran

Di Baitul Maal Mitra Anda Sejahtera, hasil wakaf yang didapatkan belum terlalu banyak. Sehingga dalam penyalurannya digabung dengan hasil infaq dan sedekah. Namun, walaupun penyalurannya diakumulasi dengan infaq dan sedekah, tetapi pencatatannya tetap sendiri. Penyaluran hasil wakaf uang tersebut sebagai berikut:

1) Dakwah. Penyaluran hasil wakaf untuk dakwah ini yaitu dengan memberikan donasi kepada segala bentuk event dakwah baik berupa komunitas pemuda Semarang, ormas, lembaga atau pihak 
yang dapat bekerjasama. Seperti halnya kajian kepemudaan yang diadakan oleh komunitas Manjadda Wajadda Semarang dan juga KREND Indonesia guna kebutuhan operasional acara tersebut.

2) Bencana dan kemanusiaan. Baitul Maal Mitra Anda Sejahtera menyalurkan bantuan secara langsung ke lokasi bencana, dan kadang bekerja sama dengan lembaga lain. Pada tahun 2018-2019, Baitul Maal Anda melakukan kerjasama dalam pengiriman bantuan bencana kepada ACT dan Solo Peduli. Penyaluran hasil wakaf uang ini bisa berupa uang, bahan sembako, pakaian ataupun sesuatu yang sesuai dengan yang dibutuhkan oleh para korban (Wawancara 11Desember 2018).

3) Pendidikan/Penghafal Quran. Baitul Maal ini menyalurkan hasil wakaf kepada beberapa pelajar yang masuk dalam kriteria orang yang menerima bantuan, bentuk penyaluran untuk pendidikan diantaranya adalah dengan memberikan uang kepada para penerima bantuan setiap bulannya berkisar 50 ribu hingga 200 ribu per orang danmemberikan pembinaan. Pembinaan ini bertujuan untuk meningkatkan keimanan, juga pengetahuan para penerima beasiswa. Pembinaan ini dilakukan secara rutin setiap bulannya. Dan pada beberapa waktu sekali diadakan pembinaan untuk orang tua penerima beasiswa pendidikan. Selain dalam bentuk uang, penyaluran hasil wakaf uang disalurkan dalam bentuk barang atau alat kebutuhan guna mensupport kegiatan belajar ke lembaga pendidikan yang membutuhkan. Contohnya yaitu pengadaan buku pelajaran, Subsidi kebutuhan listrik, pemberian bibit lele, dan juga Al-quran. Penyaluran pendidikan ini salah satunya adalah kepada SMP-SMA IT Bina Amal dan juga rumah Tahfidz Rijalul Quran.

4) Kesejahteraan Guru. Salah satu bentuk penyaluran kepada guru adalah dengan memberikan paket lebaran kepada beberapa guru dengan penghasilan dibawah UMR. Penyaluran ini yaitu kepada guru-guru TPQ dan juga beberapa guru swasta yang gajinya masih minim.

5) Ambulan. Pengadaan ambulan masih dalam proses, total pengumpulan wakaf Ambulans pada tahun 2017 adalah Rp. 4.899.071. diharapkan hasil wakaf uang mampu membeli mobil 
ambulan, membayar gaji supir dan perawat sehingga fokus melayani masyarakat dalam bidang kesehatan.

6) Yatim Piatu. Penyaluran hasil wakaf diberikan kepada yatim piatu baik dalam bentuk uang maupun barang yang sesuai dengan kebutuhan panti asuhan tersebut, selain menyaluran langsung ke rumah asuh, baitul maal Mitra Anda Sejahtera juga mengadakan sebuah acara diwaktu Ramadhan berupa buka bersama anak yatim disertai pembinaan dan penyaluran paket yatim yang berisi kebutuhan sekolah seperti tas, alat tulis maupun uang.

7) Bantuan Kesehatan. Bantuan kesehatan yang disalurkan adalah dalam bentuk cek kesehatan gratis kepada orang-orang dhuafa. Hasil wakafoperasionalnya untuk membayar perawat, dokter dan obat-obat yang diperlukan. Program ini belum dilaksanakan secara rutin dan hanya bersifat kondisional sesuai dengan jumlah wakaf yang dihasilkan maupun sesuai dengan kebutuhan masyarakat dhuafa di lingkungan yang telah dibina.

8) Qardhul Hasan. Qardhul hasan adalah pinjaman kebajikan menggunakan hasil wakaf tersebut yang kemudian para peminjamnya tidak diwajibkan membayar bagi hasilnya. Peminjam dapat mengembalikan sesuai dengan nominal pokok yang telah dipinjam sesuai dengan kesepakatan diawal. Manfaat yang diberikan kepada penerima adalah bukan berupa uang secara langsung namun berupa nilai yang didapat atas usaha yang dirintisnya sehingga dapat berjalan dan dapat meningkatkan ekonomi peminjam. Penerima Qardhul hasan ini memiliki syarat tertentu diantaranya yaitu: tidak mampu, memiliki latar belakang yang baik, jujur dan dari rekomendasi seseorang yang dapat dipercaya.

Hasil dari investasi wakaf uang digabung dengan sumber dana sosial yang lain seperti zakat, infaq dan shodaqoh. Total sumber dana penghimpunan yang diperoleh sejumlah Rp.154.819.599 (seratus lima puluh empat juta delapan ratus sembilan belas ibu lima ratus sembilan puluh sembilan rupiah) dengan rincian sebagai berikut (Laporan Penghimpunan dan Pentasharufan KSPPS Mitra Sejahtera Semarang): 


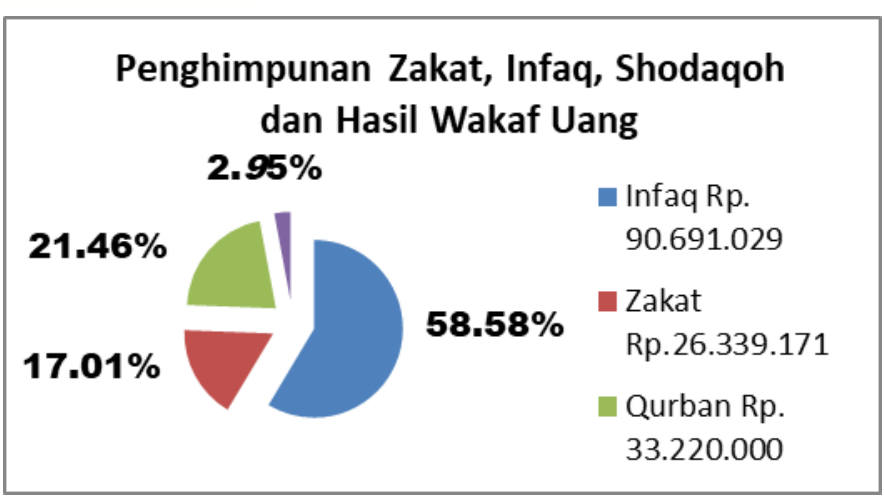

Data tersebut adalah nominal penghimpunan yang siap untuk disalurkan. Zakat, hasil investasi wakaf, infaq dan shodaqoh dihimpun menjadi satu untuk di salurkan kepada yang berhak sesuai dengan ketentuan yang telah diatur. Jumlah atau porsi kepada masyarakat sesuai dengan klasifikasi penerima adalah sebagai berikut:

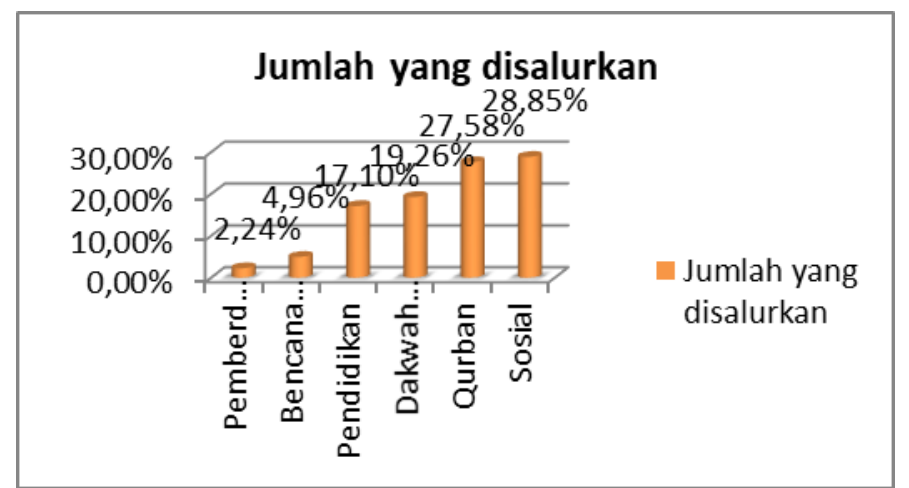

Dari data tersebut, data lebih detailnya untuk masing-masing penerima dengan klasifikasinya adalah sebagai berikut:

\begin{tabular}{llll}
\hline No. & Klasifikasi Pentasharufan & Jumlah Penerima & Total Nominal \\
\hline 1. & Pemberdayaan Ekonomi & 15 & Rp. 2.702 .834 \\
2. & Bencana dan Kemanusiaan & 119 & Rp. 5.975 .000 \\
3. & Pendidikan & 37 & Rp. 20.597 .500 \\
4. & Dakwah Islam & 235 & Rp. 23.197 .200 \\
5. & Qurban & 220 & Rp. 33.220 .000 \\
6. & Sosial & 323 & Rp. 34.743 .500 \\
Total Pentasharufan & & Rp. 120.436 .034 \\
\hline
\end{tabular}

Dari total dana yang terhimpun dari zakat, hasil investasi wakaf uang, infaq dan shodaqoh, yang siap disalurkan sebanyak Rp. 154.819.599 (seratus lima puluh empat juta delapan ratus sembilan belas ibu lima ratus sembilan puluh sembilan rupiah) dan dana yang telah tersalurkan adalah sebanyak Rp.120.436.034 (seratus dua puluh juta empat ratus tiga puluh 
enam ribu tiga puluh enam rupiah).

Kendala dan kelemahan dalam penyaluran dana-dana tersebut tetap ada, yaitu uang yang terkumpul tidak bisa langsung disalurkan kepada yang membutuhkan seperti halnya zakat infaq dan sedekah. Karena wakaf uang harus diputarkan atau diinvestasikan dahulu agar menghasilkan keuntungan sehingga dapat berumur panjang dan terus menebar kebermanfaatan. Dalam memutarkan uang yang diwakafkan pun membutuhkan waktu, tenaga dan pikiran sehingga harus melalui proses yang lebih panjang. Hasil yang didapatkan pun tidak selalu banyak. Karena dalam usaha mengelola uang atau investasi terkadang tidak sesuai dengan yang diprediksikan. Dalam mengelola wakaf uang, juga mengeluarkan biaya operasional yang tidak sedikit.

\section{SIMPULAN}

Penghimpunan wakaf uang di Baitul Maal KSPPS Mitra Anda Sejahtera mencapai 41 juta rupiah hingga akhir 2018. Penghimpunan wakaf uang yang dilakukan Baitul Maal KSPPS Mitra Anda Sejahtera melalui jemput bola ke wakif, syiar di sosial media, transfer, atau wakif langsung menyetorkan ke kantor Baitul Maal KSPPS Mitra Anda Sejahtera. Penerapan wakaf uang di lembaga ini belum optimal sesuai prosedur yang telah diatur oleh Peraturan Pemerintah, seperti membuatkan sertifikat wakaf, menuliskan dan membacakan ikrar, menuliskan secara jelas identitas wakif, asal- usul dana tersebut dan kegunaannya wakaf untuk apa (sesuai kehendak wakif) dll.

Pengelolaan wakaf uang di KSPPS Mitra Anda Sejahtera dengan investasi deposito, jual beli hewan quban, peminjaman untuk modal usaha dengan bagi hasil kecil atau tidak memungut bagi hasil sama sekali. Dalam pengelolaan wakaf uang di KSPPS Mitra Anda sejahtera juga belum optimal karena kurangnya SDM dan relasi yang dimiliki. Dalam menginvestasikan wakaf uang KSPPS Mitra Anda Sejahtera sangat berhatihati karena pada prinsipnya wakaf uang itu harus kekal dana yang diinvestaikan sehingga membuat pengelola takut untuk mengambil resiko yang akhirnya hasil atau keuntungan yang diperoleh tidak banyak. Dalam memperoleh keuntungan atau hasil wakaf yang tidak banyak itu membuat penyalurannya juga sedikit. Penyaluran dana wakaf uang di Baitul Maal KSPPS Mitra Anda Sejahtera diantaranya untuk program membeli 
ambulans dan memanfaatkannya untuk pelayanan masyarakat, pengadaan Al-quran di pesantren Tahfidzul Quran, santunan guru, dakwah, kemanusiaan atau bencana alam, kesehatan, anak yatim dan pinjaman kebajikan atau qardhul hasan.

\section{DAFTAR RUJUKAN}

Arif Zamhari, dkk. (ed), Manajemen Wakaf di Era Modern, (Jakarta, Badan Wakaf Indonesia, 2013)

Djunaidi dkk, Strategi Pengembangan Wakaf Tunai di Indonesia, (Jakarta: Depag RI,2007) Fatwa Majelis Ulama Indonesia, tahun 2003 tentang wakaf uang.

Direktorat Pemberdayaan Wakaf Direktorat Jenderal Bimbingan Masyarakat Islam Departemen Agama RI, Fiqih Wakaf, cet 4, Jakarta, 2006

Direktorat Pengembangan Zakat dan Wakaf, Proses Lahirnya Undang-Undang No. 41 Tahun 2004 Tentang Wakaf (Jakarta:

Direktorat Jenderal BimasIslam Departemen Agama RI, 2006)

Ishom, Muhammad. 2014. Efektivitas Undang-Undang No.41 Tahun 2004 Tentang Pengaturan Wakaf Produktif.Jurnal Bimas Islam. Vol.7 (IV)

Kementerian Agama Republik Indonesia Direktorat Jendral Bimbingan Masyarakat Islam Direktorat Pemberdayaan Wakaf, Fiqih Wakaf, 2006

Makhrus, M. (2019). Dinamika Kebijakan Negara dalam Pengelolaan Wakaf di Indonesia. JSSH (Jurnal Sains Sosial dan Humaniora), 2(2), 209-224.

Komisi fatwa Majelis Ulama Indonesia (2003:85) tanggal 11 Mei 2002

"Wakaf Tunai- Investasi Abadi Manfaatnya Mengalir Tiada Henti," https://www.hidayatullah.com, akses 2 Maret 2007.

Muh.Fudhail Rahman, "Wakaf Dalam Islam", Al-Iqtishad, Vol. 1 No. 1 (Januari, 2009).

M.A. Mannan, Sertifikat Wakaf Tunai Sebagai Inovasi Instrumen Keuangan Islam, (Jakata: CIBER-PKTI-UI, t.t)

Monzer Kahf, "Financing the Develpoment of Awqaf Property," makalah disampaikan pada Seminar Development of Awqaf (Kuala Lumpur, 2-4 Maret 1998)

Muhammad Maksum, Jurnal Ekonomi Islam, Manajemen Investasi Wakaf Uang,UIN Syarif Hidayatullah

Muhammad Abu Zahrah, Muhadharat Fi al-Auquf, (Beirut: Dar al-Fikr, 1971) 
Peraturan Pemerintah Nomor 42 tahun 2006 tentang pelaksanaan Undang-Undang Nomor 41 tahun 2004 tentang Wakaf.

Republika, Manajemen Fundraising dalam Penghimpunan Wakaf, 16 Desember 2008.

Rozalinda, Manajemen Wakaf Produktif, (Jakarta: PT Raja Grafindo Persada, 2015)

Rachmadi Usman, Hukum Perwakafan di Indonesia, cet. Kedua (Jakarta: Sinar Grafika, 2013)

Sudirman, Pengembangan Wakaf Tunai untuk Keadilan Sosial, Jurnal Ekonomi dalam Hukum Islam, (Dosen UIN Maulana Malik Ibrahim, 2009)

Sudirman Hasan, Wakaf Uang Perspektif Fiqih, Hukum Positif dan Manajemen, (UIN Maliki Press, 2011)

Sudirman Hasan, Wakaf Uang dan Implementasinya di Indonesia, Jurnal Ekonomi Islam.

Suharto, Edy. 2005. Membangun Masyarakat, Memberdayakan Rakyat. Surabaya: Aditama.

Wawancara dengan pengelola KSPPS Mitra Anda Sejahtera, Bapak Catur Prasetyo, tanggal 4 Januari 2019di kantor KSPPS Mitra Anda Sejahtera Wawancara, dengan pengelola Baitul Maal Anda, Bapak Mahatma Yusuf, pada 11 Desember 2018. 